\title{
ACCESSING THE GLOBAL INTELLECTUAL PROPERTY MARKET: INTELLIGENT DECISIONS ABOUT PATENT PROTECTION
}

\author{
Seth D. Levy \\ Esq., Of Counsel Davis Wright Tremaine LLP
}

Seth D. Levy, Esq. received his B.S. in Agricultural and Biological Engineering from Cornell University, and his Juris Doctorate from the University of Southern California Law School. Mr. Levy is Of Counsel to the international law firm Davis Wright Tremaine LLP. He is a patent attorney based in the firm's Los Angeles, California office, where his practice focuses primarily on the representation of universities and research institutions in the U.S. and abroad. E-mail: sethlevy@dwt.com

\begin{abstract}
Patent protection can be a tremendously useful tool for transferring technology from the research laboratory to the commercial marketplace. However, many misconceptions exist - especially in the academic world - about how to effectively and efficiently make use of patent protection. By overcoming some of the common myths and making informed decisions about when and where to pursue patent protection, research institutions and their scientists can benefit significantly. Patent protection is available across a wide range of technologies, but the availability of patent protection alone may not be a sufficient basis upon which to determine whether to pursue patent protection. This is because the mere availability of patent protection does not necessarily equate to commercial viability of the underlying technology. Thus, a further analysis of the technology's commercial potential can be quite important in making informed decisions about the patent process.
\end{abstract}

In countries around the world and in research across nearly every field of technology and innovation, patents provide a means to harvest the value of inventions and control their distribution and use. A patent provides its owner the right to exclude others from making, using and selling the subject matter of the patent [1]. These important rights enable the patent holder to control, during the term of the patent, the development and commercial distribution of its technology.

\section{The Importance of Patenting}

For academic and research institutions, patent protection can be a particularly effective vehicle for ensuring that technology developed in the laboratory is not only the subject of scholarly publication, but also becomes embodied in a product or service that reaches the marketplace in a manner that allows the public to benefit from scientific advances. Patent protection additionally provides a vehicle for the individuals and institutions whose innovative contributions and financial resources are used to be compensated for their academic and economic investment. All too frequently, important science developed at universities and other research institutions is commercialized by companies in the private sector without any rewards - monetary or otherwise - to the university or institution, or to its scientists. 


\section{Special Issue}

Patents are a principal intellectual property mechanism that researchers and their institutions can utilize to protect scientific advances and secure some financial return when those advances are embodied in commercial products and services. This often occurs through the establishment of a business relationship between the academic institution and/or scientist and a company in the private sector. Depending upon local law and the preferences of the institution or its researchers, as well as the stage in development and other aspects of the technology at issue, such business relationships can take any number of forms. For instance, these relationships might involve the license or sale of the patents and/or patent applications relating to the technology, but can also involve the establishment of new companies with venture capital financing or more expansive collaborative research arrangements. Alternatively, if, without an existing business relationship, a company commercializes a product or service that infringes on the rights of a patent holder, whether that patent holder is a large academic institution or an individual scientist, the institution or scientist may seek enforcement of its intellectual property rights through legal proceedings. If successful, such legal proceedings should result in the patent holder being awarded monetary damages based on the illicit commercialization of its patented product or service. Whether a business relationship is formed to commercialize a product or a patent holder pursues legal action to enforce its intellectual property rights, the goal is the same: securing a financial return for the commercialization of technology developed at the institution. Absent patent protection, this can be a difficult or entirely impossible goal for an academic institution or its researchers to achieve.

In fact, the existence of patent protection for technology developed at an academic institution can be a critical issue for companies in the private sector insofar as the company's interest in a business opportunity with the institution is concerned. If an institution is conducting research in a particular field and diligently pursuing patent protection, then there are likely to be legitimate intellectual property assets for companies to purchase or license. Once a company acquires an interest in that intellectual property, it may enjoy a significant advantage in the market with respect to its competitors. The added leverage of licensed patents can be a tremendous advantage for companies that would otherwise be left to simply compete in the marketplace. Indeed, strong patent protection can offer the company a period of market exclusivity. The possibility of effective market exclusivity can be critical for the company's business objectives. This is important for academic and research institutions to appreciate, if attracting licensing revenue or research funding from the private sector is of interest.

Furthermore, it is often the case that technology developed at academic or research institutions for which patent protection is not sought is not commercialized. Without the possibility of market exclusivity through patent protection, companies may not have any interest in devoting the necessary time and resources to commercializing the unpatented product. This is frequently the case in the fields of biotechnology and the life sciences, where the existence of patent protection can mean the difference between a company taking an interest in commercializing a technology or ignoring it entirely. Thus, if an institution's goal is to see the technology it develops reach the public, then patent protection may be a critical issue to consider.

In sum, patents provide a mechanism for academic institutions and their scientists to reap the financial rewards of scientific successes, while also providing an incentive for companies to partner with institutions and scientists in bringing their technology to market.

SCIENCE AND INNOVATION. N 4, 2005 


\section{Technologies, innovation management and technology transfer}

\section{Determining Whether Patent Protection is Appropriate}

Patent protection can be an important component of collaborations between academic and research institutions and companies in the private sector. However, patent protection is not available in every instance, and, even in those instances where it is available, pursuing patent protection is not always advisable. It is thus important to consider whether patent protection is appropriate before investing the resources required to procure it. This is especially true at academic and research institutions, where limited resources may be available for this sometimes costly process.

Before seeking patent protection, it is worthwhile to first consider if an innovation is patentable. This is a preliminary question that many institutions and scientists routinely investigate before initiating the patenting process. Oftentimes, however, the preliminary inquiry ends at that stage, and the decision on whether to pursue patent protection is based merely on whether that protection seems to be available. Yet, if patent protection seems to be available, there is a second and quite important issue to consider. That is whether patent protection would be valuable. Indeed, there are many instances where an invention meets all of the legal and technical requirements for patentability, and a patent can therefore be obtained. But the mere fact that an invention is patentable does not mean that the technology is inherently valuable. More specifically, it does not mean that business opportunities will exist or that the technology will be commercialized. If business opportunities do not exist and the technology will not be commercialized, then there is not likely to be much value for an academic institution in having secured patent protection. Indeed, even the most exciting academic advances may not have any commercial relevance.
It is therefore important, especially for academic institutions, to consider whether there is significant commercial potential for a technology before seeking patent protection, or at a minimum, to consider this issue early in the patenting process. It is the commercial potential of a technology, and not its academic interest alone, that makes patent protection worthwhile.

\section{Assessing Patentability}

In most countries, an invention is patentable if is meets several requirements: it must be novel [2], it must involve an inventive step (or is "non-obvious") [3], and it must have industrial applicability (or "utility") [4]. Particularly in the fields of biotechnology and the life sciences, one must additionally consider if the invention can be adequately described and defined so as to support patent claims. It is often the case that research in these fields provides important insight into the physiology of a human or animal system, such as by discovering a relevant gene or molecular target. However, while such discoveries may have tremendous importance for understanding health and disease, it does not necessarily translate into a patentable pharmaceutical or diagnostic technique without substantial further research.

An invention is typically deemed to be novel if it was not known prior to its discovery (and the filing of a patent application) by the inventor. Inventive step is generally based on a determination that the invention would not have been obvious to a skilled artisan in that scientific field. These issues - novelty and inventive step - are at the center of the patenting process, and result in the greatest amount of discussion and disagreement between patent applicants and patent offices around the world. Industrial applicability, however, is typically not a significant obstacle to obtaining a patent, so long as a patent application is directed solely to subject matter for which patent protection is 


\section{Special Issue}

available in a particular jurisdiction. For example, laws of nature are generally not patentable, and in some locations, methods of medical or surgical treatment are not patentable [5]. Similarly, patent protection is available only to limited degrees in many countries for computer software inventions.

Patentability is typically assessed by conducting a review of the prior art to determine if the invention meets the criteria for patentability (i.e., novelty, inventive step) in jurisdictions of interest. Any concerns regarding unpatentable subject matter or research that cannot support patent claims are also assessed.

\section{Evaluating Commercial Potential}

A patent is a useful mechanism to protect and harvest the value of an invention to the extent that value actually exists or is likely to exist in the foreseeable future. Some inventions have far greater commercial value than others. This often appears contrary to the importance of an invention from a purely academic perspective. Consider, for example, two new pharmaceuticals; one that is effective in treating a commonplace yet serious medical condition prevalent in adults around the world, and another that is useful in the treatment of a disease that has no discernable symptoms or means of diagnosis and affects few people. In this very basic example, it should be clear why a patent for the former could have significant commercial value (based on the size of the market and the severity of the condition) while the opposite is likely to be true for the latter (based on the limited market size and the lack of ability to readily diagnose the condition). This is a very simple example, but underscores the importance of considering the commercial potential of an invention before investing resources in securing patent protection. Indeed, the question of a technology's potential commercial value is typically much more complex. One must consider an array of factors, and these factors will vary across different technologies. Some, but not all of these factors include the following.

\section{Size and Nature of the Market}

The size and nature of the market for a technology are important factors to consider. A product that is expected to be purchased by many people could be more valuable than a product that only few people find useful. However, despite the fact that the size of a market may be very small, a product that sells at a high price may still have significant commercial value. Another consideration is whether one or more comparable products already exist in the market, or whether the invention relates to truly new technology that can itself define a new market.

\section{Relevant Business Transactions}

In most cases, an academic institution or individual scientist will not commercialize a product on its own. Instead, a business relationship will be formed with a company in the private sector that is better positioned to commercialize the technology. These relationships typically involve either a license or sale of the patents or other forms of intellectual property protection that relate to the technology. Thus, gaining an understanding of the types of terms that can be expected in such a transaction can be quite informative. The financial terms may include licensing fees, royalties for product sales, milestone payments, equity in a company, or a host of other forms of consideration. It may be helpful to know, for example, that the vast majority of the licenses for a particular type of technology involve a small, one-time licensing fee, rather than more robust royalty provisions based on product sales.

Depending upon the area of technology and the particular industry in which it finds applica-

SCIENCE AND INNOVATION. N 4, 2005 
tion, certain relevant information can be obtained through a variety of sources. There are a number of services to which one can subscribe that compile this type of information on a regular basis. Additionally, in some countries, such as the United States, publicly traded companies are required to make certain information available to the public. In certain instances, this can include the details of the companies' licensing transactions and other business arrangements with academic and research institutions. A number of other sources can also be examined for information in this respect.

\section{Legal Obstacles to Commercialization}

The commercial value of a new technology can be significantly impacted by the scope of related patent protection that has been obtained by others in the field. For example, it is not uncommon for medical research to identify a new use for an existing pharmaceutical for which one or more patents are held by a particular company. Depending upon the nature of that company's patent protection, it may be impossible to commercialize the novel indication without the consent of that company. To proceed otherwise may result in an infringement of the company's patents. Even if a tremendous market exists for the novel indication and it seems to be overwhelmingly valuable upon examination of similar business transactions, the technology may not be licensable to anyone other than that one company. This can be a challenging situation for an academic or research institution. If the company is interested in a business transaction (e.g., because it extends the possible patent coverage for the product), then that may generate a positive result for the institution. If, however, the company is not interested in a business transaction, the institution may have difficulty identifying other business partners.

SCIENCE AND INNOVATION. N 4, 2005
Public Perception

Particularly in the life sciences and biotechnology, one must consider the public perception of a technology to understand whether it is likely to be successful in the market. By way of example, advances in gene therapeutics and stem cell research have created exciting new possibilities for scientific and medical breakthroughs. However, the public outcry in various parts of the world about the routine implementation of these technologies should be considered in assessing the breadth of companies in the private sector that may be interested in attempting to commercialize these technologies and the likelihood that a commercial product will reach the market.

\section{Where to Pursue Patent Protection}

Once a decision is made to pursue patent protection, one must consider where to do so. One common misconception is that one can obtain a single "international patent." This is not true. Certain international treaties provide a harmonized system for filing patent applications and pursuing patent protection [6], but, ultimately, patents are awarded on a country-by-country basis. Thus, patent applicants must decide where to pursue patent protection.

While there are a range of issues to consider in making this determination, three general themes apply across a wide range of technologies typically developed at academic and research institutions. First, one might consider where the technology will actually be marketable and have cognizable commercial value. Countries with a limited or nonexistent market for a particular technology are generally not worthwhile jurisdictions in which to pursue patent protection. Second, one might weigh the possible market value of a technology in a particular country against the cost of obtaining patent protection. In some countries, pursuing 


\section{Special Issue}

patent protection can be quite expensive, and the potential return on that investment may not be sufficient to justify seeking patent protection. Third, one must consider whether patent protection is generally enforceable in a particular country of interest. Some countries have effective systems in place that enable patent holders to enforce their patents against infringers, while enforcement in other countries can be challenging. Before incurring the expense of patent protection, one must consider whether it will be an effective tool to protect the patent holder's intellectual property rights in that country.

\section{Publishing versus Patenting}

One of the most prevalent myths associated with pursuing patent protection is the idea that one must choose between either patenting or publishing the results of one's research. It is simply not true that one must choose one or the other. Quite to the contrary, it is entirely commonplace for scientists at academic and research institutions to publish the results of their research in scholarly journals and to present the same at conferences, while also (usually simultaneously) pursuing patent protection. The misconception among scientists that these are mutually exclusive is a significant obstacle for academic and research institutions that wish to protect the intellectual property developed by their researchers.

There is an extremely important caveat, however. While one need not choose between patenting and publishing, these activities are interrelated and must be carefully coordinated to avoid the loss of patent rights. Most countries require that a patent application be filed prior to any public disclosure of the invention. This requirement is referred to as "absolute novelty." Most countries define a "public disclosure" as a publication, oral presentation, public display or public use. It would thus not be pos- sible to obtain a valid patent in an "absolute novelty" country if the invention is publicly disclosed prior to filing a patent application. Absolute novelty countries include, for example, countries that are party to the European Patent Convention [7], Japan, and Ukraine. This is slightly different in the United States, where inventors have a one-year grace period in which to file a patent application following public disclosure or the offer for sale or actual sale of a product or service that embodies their invention [8].

The ability to freely and expeditiously publish the results of one's research is critical to many in academia. It is therefore equally critical that academic and research institutions have available to them resources to speedily file patent applications where necessary to protect inventions without hampering scientists' freedom to publish or disclose the results of their research. Internal systems can be established at academic institutions to account for this concern, and efficient patent counsel can typically prepare and file a patent application without requiring significant delay in the publication or disclosure of an invention. In fact, in the United States, a mechanism is available that enables a patent applicant to file a "provisional" patent application, which does not require all of the formalities of a standard patent application [9]. This mechanism is often used when a patent application must be filed quickly.

\section{Timeline for Patenting}

The Patent Cooperation Treaty ("PCT") is the principal mechanism that makes it possible to seek patent protection for an invention simultaneously in multiple countries. An international patent application may generally be filed with a national patent office of a country that is party to the PCT (or with the International Bureau of the World Intellectual Property Organization in Geneva). Where appropriate, the application 
may alternatively be filed with the European Patent Office ("EPO"), the African Regional Industrial Property Organization ("ARIPO") or the Eurasian Patent Office ("EAPO"). This application may include a claim of priority to a domestic patent application filed no more than one year prior to the filing of the international application.

Once the international patent application is filed, the applicant must initiate national phase prosecution in each jurisdiction of interest before the expiration of the particular national phase filing deadline. Depending upon the country or region and the manner in which the applicant conducted the international phase of patent prosecution, this deadline can be anywhere from 20 to 42 months from the application's filing or priority date; although, in most countries, the deadline is either 30 or 31 months.

After national phase prosecution is initiated, the speed with which patent offices around the world conduct patent prosecution varies dramatically. On average, however, a patent applicant can typically expect a patent to issue within about 3-4 years of initiating national phase prosecution. In most jurisdictions, a patent has a term of 20 years, measured from its earliest priority date.

1. See, e.g., 35 United States Code $§ 271$.

2. See, e.g., 35 United States Code $\S 102$; European Patent Convention Articles 52(1) and 54.

3. See, e.g., 35 United States Code $§ 103$; European Patent Convention Articles 52(1) and 56.

4. See, e.g., 35 United States Code $\S 101$; European Patent Convention Articles 52(1) and 57.

5. See, e.g., European Patent Convention Article 52(4).

6. See, e.g., the Paris Convention for the Protection of Industrial Property (1883), the Patent Cooperation Treaty (1970), the Patent Law Treaty (2000), the Budapest Treaty on the International Recognition of the Deposit of Microorganisms for the Purposes of Patent Procedure (1977), and the Strasbourg Agreement Concerning the International Patent Classification (1971).

7. Article 54(2) of the European Patent Convention (EPC) creates an "absolute novelty" requirement. EPC countries presently include Austria, Belgium, Bulgaria, Switzerland, Cyprus, Czech Republic, Germany, Denmark, Estonia, Spain, Finland, France, United Kingdom, Hellenic Republic, Hungary, Ireland, Iceland, Italy, Liechtenstein, Lithuania, Luxembourg, Latvia, Monaco, Netherlands, Poland, Portugal, Romania, Sweden, Slovenia, Slovakia and Turkey.

8. $\quad$ See 35 United States Code $\S \S 102(a), 102(b)$

9. $\quad$ See 35 United States Code $§ 111$. 